\title{
Financial Attitude and Management of Public School Teachers in Tanjay City
}

\author{
Benjamin S. Villagonzalo, Jr. ${ }^{1}$ and Rizalie N.E. Mibato ${ }^{2}$ \\ ${ }^{1}$ Negros Oriental State University, Dumaguete City, Philippines \\ ${ }^{2}$ University of Negros Occidental-Recoletos, Bacolod City, Philippines
}

\begin{tabular}{l} 
Article history \\
Submitted: 26 October 2020 \\
Revised: 5 November 2020 \\
Accepted: 10 November 2020 \\
\hline Keywords \\
Business Management \\
Financial Attitude \\
Financial Management \\
Public School Teachers \\
Descriptive-Correlational \\
Tanjay City
\end{tabular}

Introduction. Teachers are influential individuals in the society. They can positively influence various aspects of people's lives. If financially learned, they can become role models for students and help develop a financially responsible family. Thus, teachers are key contributors to the development of society. This study aimed to assess the degree of financial attitude and the level of financial management of public elementary school teachers in Tanjay City, Negros Oriental during the School Year 2019-2020 as a whole and when grouped according to age, sex, civil status, educational attainment, family monthly income, and location of residence. It also sought to establish if there is a significant difference in the degree of their financial attitude and their level of financial management when they are grouped according to the variables. It also determined if a significant relationship exists between financial attitude and financial management. Findings were used for a financial literacy program that seeks to improve the financial attitude and financial management of the said teachers.

Methods. This study utilized a descriptive, comparative, and correlational design where the descriptive design was used to assess the degree of financial attitude and level of financial management of the 220 public elementary school teachers. Descriptive analysis using Mean and Standard Deviation was employed to interpret the data. The comparative design was used to test significant differences in the degree of financial attitude and level of financial management of the respondents when grouped according to the variables age, sex, civil status, educational attainment, family monthly income, and location of residence. Comparative analysis using ANOVA and t-test was employed to treat the data. Lastly, correlational design was used to assess the significant relationship between financial attitude and financial management. Data underwent correlational analysis using Pearson $r$.

Results. Overall, findings reveal that the degree of the financial attitude of the respondents is "disagree," both when they are taken as a whole and grouped according to variables age, sex, civil status, educational attainment, family income, and location of residence. When the areas of financial attitude were investigated, only the area financial discipline showed "agree". In contrast, financial planning and financial implementation showed "disagree" results on the degree of financial attitude. For financial management, when the respondents are taken as a whole and grouped according to the variables age, sex, civil status, educational attainment, family income, and location of residence, the level is "good". When the areas of financial management were surveyed, the level of financial management in terms of saving and investing is "good", while that of spending and borrowing is "very good." Finally, the results revealed that there is no significant relationship between financial attitude and financial management.

Conclusion. Positive financial attitude begets wise decision-making on the part of the individuals to handle their financial resources well, while unhealthy and poor financial attitudes toward money lead individuals to poor financial decisions. It was presumed that there are factors that affect the individuals' financial attitude; however, said presumptions had been proven otherwise because age, sex, civil status, educational attainment, family income, and location of residents do not influence their financial attitudes. Regardless of demographics, all need to have the right attitude towards handling financial resources. The areas of financial attitudes, such as financial discipline, financial planning, and financial implementation, are not dependent on the demographics of the individuals. Regardless of age, sex, civil status, educational attainment, family income, and location of residence, 
financial management skills need to be enhanced for individuals to better handle financial decisionmaking that will lead to financial satisfaction. Financial practices in saving, spending, borrowing, and investing need to be attended to by a sound financial literacy program.

Practical Value of the Paper. Considering the dearth of relevant researches and the alarming conditions involving the financial attitude and financial management of the teachers in public elementary schools in Tanjay City, Negros Oriental, this study was conducted not only to contribute to existing literature but also to utilize the knowledge derived to address the issues on hand. With the result of the study, a financial literacy program was designed to address the needs of the teachers to enhance their financial capability.

\section{References}

Agarwal, S., Amromin, G., Ben-David, I., Chomsisengphet, S., \& Evanoff, D. D. (2015). Financial literacy and financial planning: Evidence from India. Journal of Housing Economics, 27, 4-21. https://doi.org/10.1016/j. jhe.2015.02.003.

Ansong, A., \& Gyensare, M. A. (2012). Determinants of University Working-Students' Financial Literacy at the University of Cape Coast, Ghana. International Journal of Business and Management, 7(9), 126-133. https:// doi.org/10.5539/ijbm.v7n9p126

Archuleta, K. L. (2013). Couples, money, and expectations: Negotiating financial management roles to increase relationship satisfaction. Marriage \& Family Review, 49(5), 391-411. doi: 10.1080/01494929.2013.766296

Bhushan, P., \& Medury, Y. (2013). Financial Literacy and its Determinants. International Journal of Engineering, Business, and Enterprise Applications (IJEBEA), 4(2), 155-160. Retrieved from https://shorturl.at/mwzM2

Cepeda, M. (2017). Briones eyes mandatory financial literacy workshops for teachers. Retrieved December 27, 2018, from https://www.rappler.com/nation/briones-mulls-mandatory-financial-literacy-workshops-teachers

Gale, W. G. \& Levine, R. (2010). Financial literacy: What works? How could it be more effective? Brookings Institution. Retrieved from http://dx.doi.org/10.2139/ssrn.2316933

Hastings, J., \& Mitchell, O. S. (2018). How financial literacy and impatience shape retirement wealth and investment behaviors. Journal of Pension Economics and Finance, 19(1), 1-20. https://doi.org/10.1017/s1474747218000227

Huston, S. J. (2010). Measuring Financial Literacy. Journal of Consumer Affairs, 44(2), 296-316. https://doi. org/10.1111/j.1745-6606.2010.01170.x

Loke, Y. J. (2017). The influence of socio-demographic and financial knowledge factors on financial management practices of Malaysians. International Journal of Business and Society, 18(1), 33-50. https://doi.org/10.33736/ ijbs.488.2017

O'Neill, B. M., \& Hensley, B. J. (2016). Building the Financial Education Capacity of Teachers: Does It Make a Difference? International Handbook of Financial Literacy, 639-654. https://doi.org/10.1007/978-98110-0360-8_40

Young, J. H. (2013). Financial literacy: Age and experience as the determinants. Washington Business Research Journal, 3(1), 35-45. Retrieved from shorturl.at/aceCR

\section{Correspondence:}

Benjamin S. Villagonzalo, Jr. [villagonzalobenjamin@gmail.com]

https://orcid.org/0000-0001-5019-3558 